\title{
Isotope hydrology and water sources in a heavily urbanised stream
}

\author{
Christian Marx ${ }^{1}$, Doerthe Tetzlaff ${ }^{2}$, Reinhard Hinkelmann ${ }^{1}$, and Chris Soulsby ${ }^{3}$ \\ ${ }^{1}$ Technische Universität Berlin \\ ${ }^{2}$ Leibniz-Institut für Gewässerökologie und Binnenfischerei im Forschungsverbund Berlin eV \\ ${ }^{3}$ University of Aberdeen
}

April 27, 2021

\begin{abstract}
Complex networks of both natural and engineered flow paths control the hydrology of streams in major cities through spatiotemporal variations in connection and disconnection of water sources. We used spatially extensive and temporally intensive sampling of water stable isotopes to disentangle the hydrological sources of the heavily urbanized Panke catchment ([?] 220 $\mathrm{km}^{2}$ ) in the north of Berlin, Germany. The isotopic data enabled us to partition stream water sources across the catchment using a Bayesian mixing analysis. The upper part of the catchment streamflow here is dominated by groundwater from gravel aquifers underlying surrounding agricultural land. In dry summer periods, streamflow becomes intermittent; possibly as a result of local groundwater abstractions. Urban storm drainage is also an important part of runoff generation, dominating the responses to precipitation events. Although this dramatically changes the isotopic composition of the stream, it only accounts for $10-15 \%$ of annual streamflow. Moving downstream, subtle changes in sources and isotope signatures occur as catchment characteristic vary and the stream is affected by different tributary inflows. However, effluent from a wastewater treatment plant (WWTP) serving 700,000 people dominates the stream in the lower catchment where urbanisation effects are more dramatic. The associated increase in sealed surfaces downstream also reduces the relative contribution of groundwater to streamflow. The volume and isotopic composition of storm runoff is again dominated by urban drainage. As a result, only about $10 \%$ of annual runoff in the lower catchment comes from urban storm drains. The study shows the potential of stable water isotopes as inexpensive tracers in urban catchments that can provide a more integrated understanding of the complex hydrology of major cities. This offers an important evidence base for guiding the plans to develop and re-develop urban catchments to protect, restore and enhance the ecological and amenity value of these important resources.
\end{abstract}

\section{Hosted file}

HP_1_fin.pdf available at https://authorea.com/users/410242/articles/519702-isotopehydrology-and-water-sources-in-a-heavily-urbanised-stream 

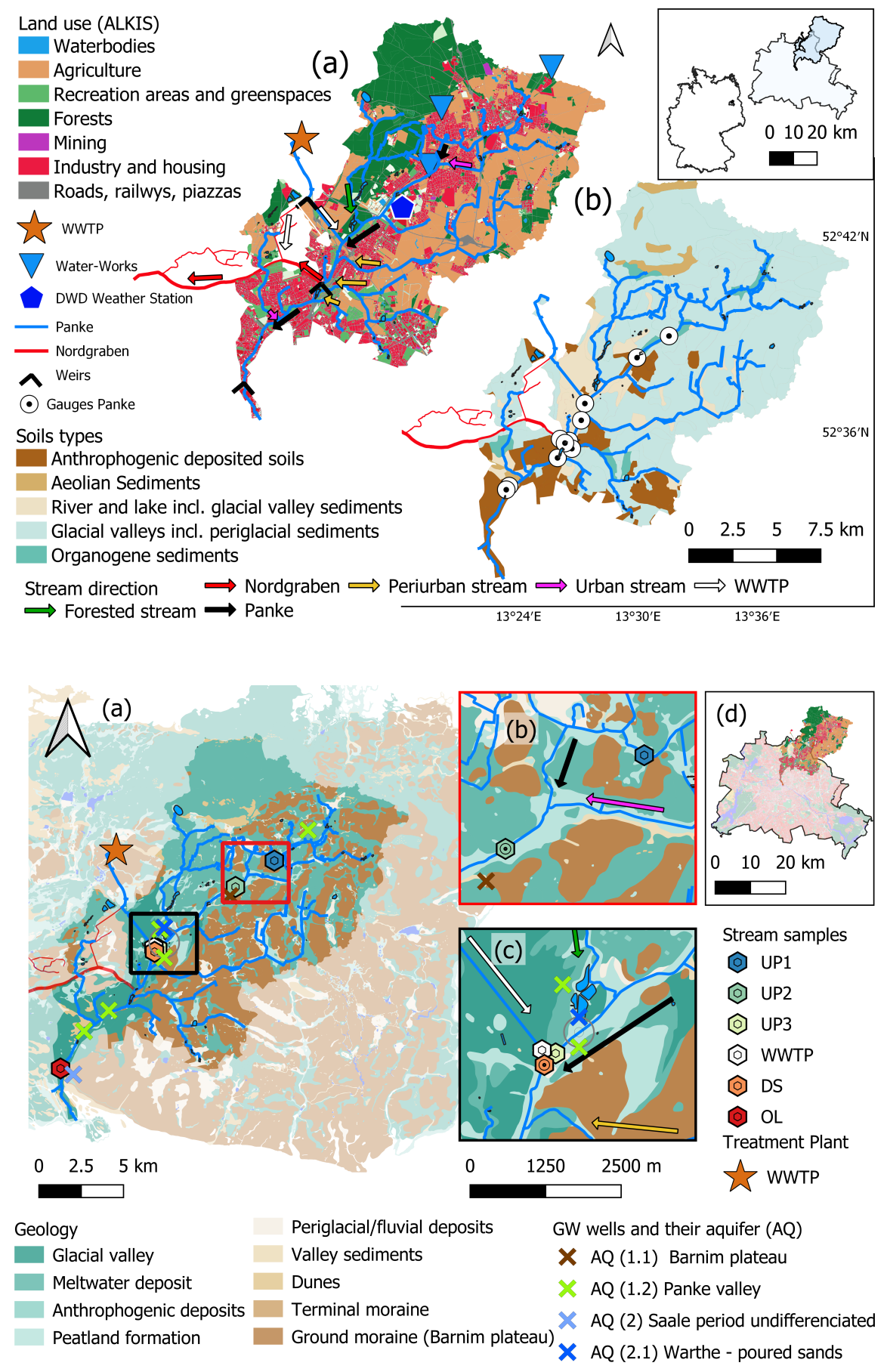

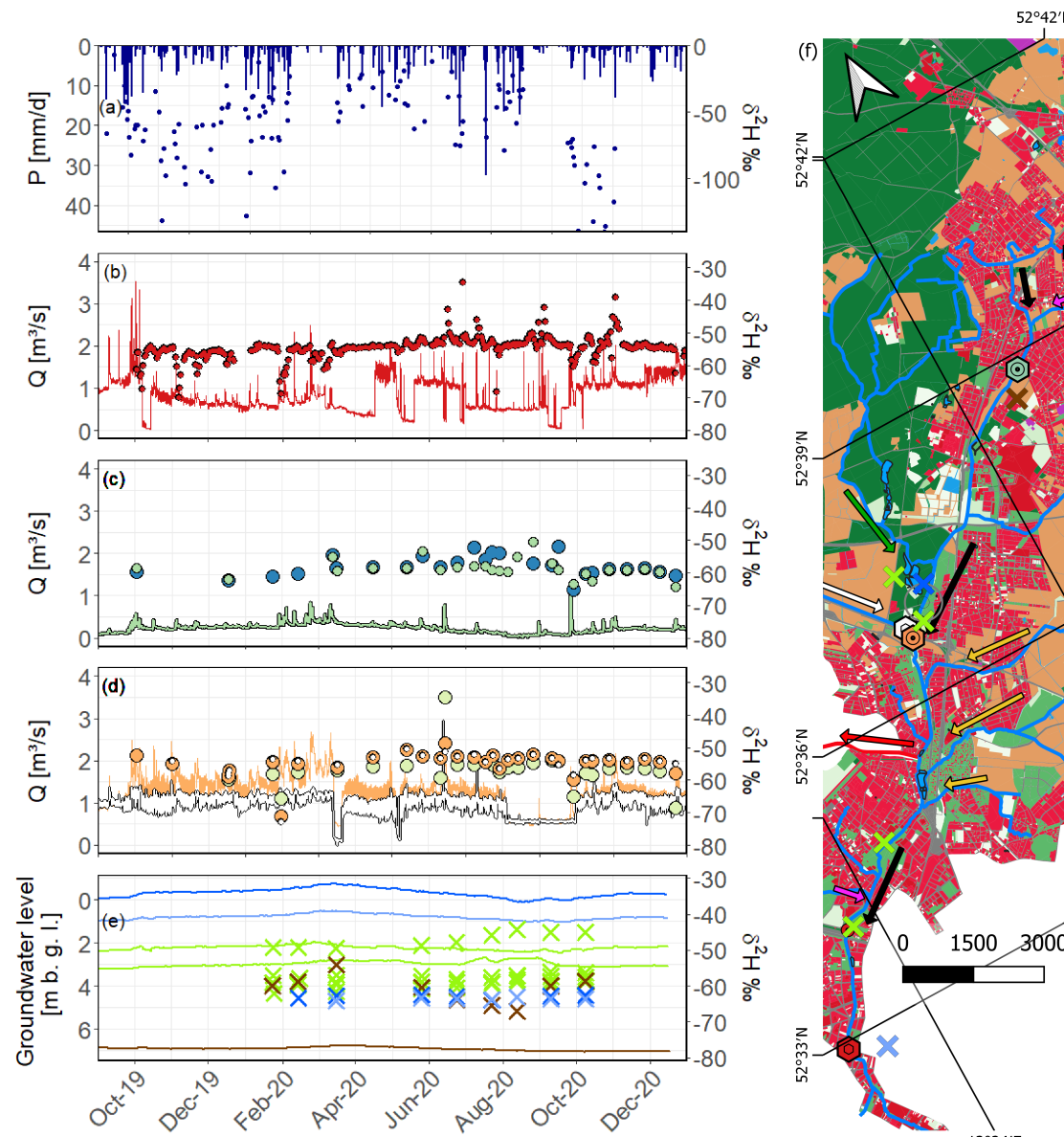

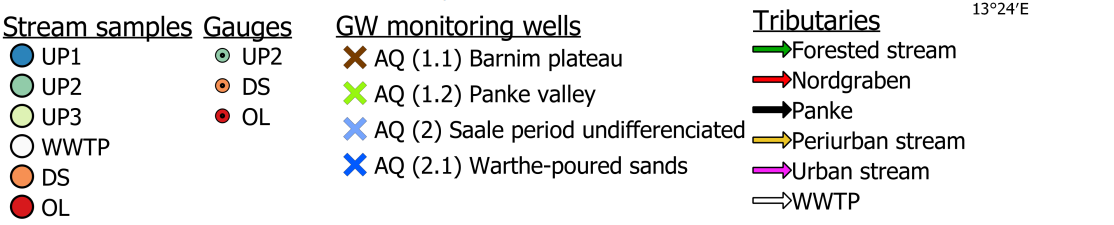



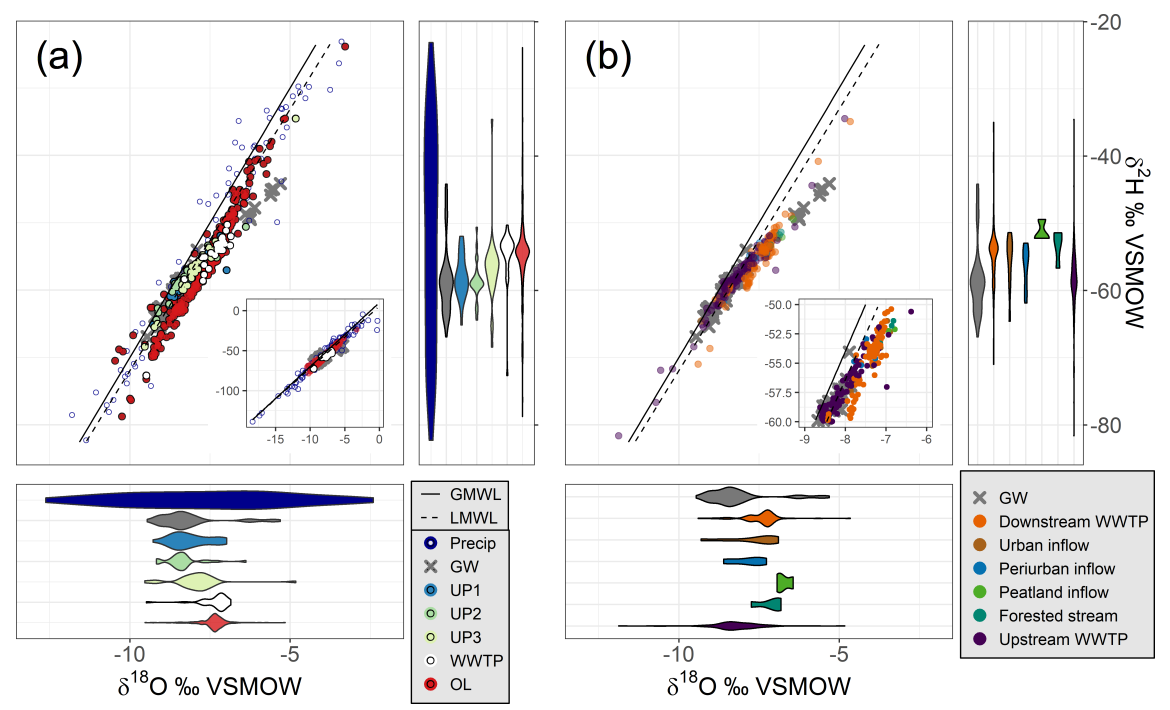


\section{October 2019 December 2019 April 2020 July 2020}
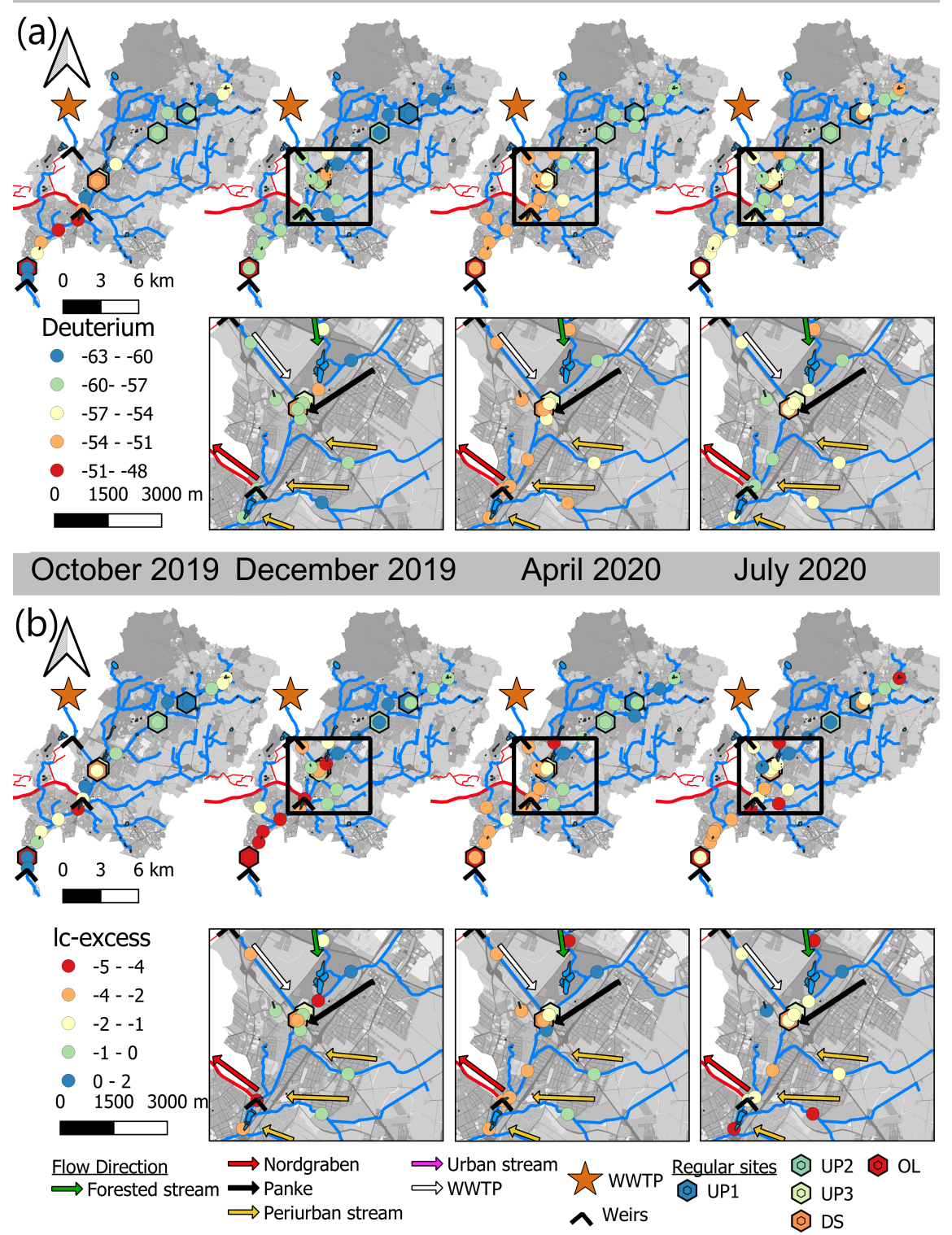

\section{Hosted file}

Fig7.pdf available at https://authorea.com/users/410242/articles/519702-isotope-hydrologyand-water-sources-in-a-heavily-urbanised-stream 


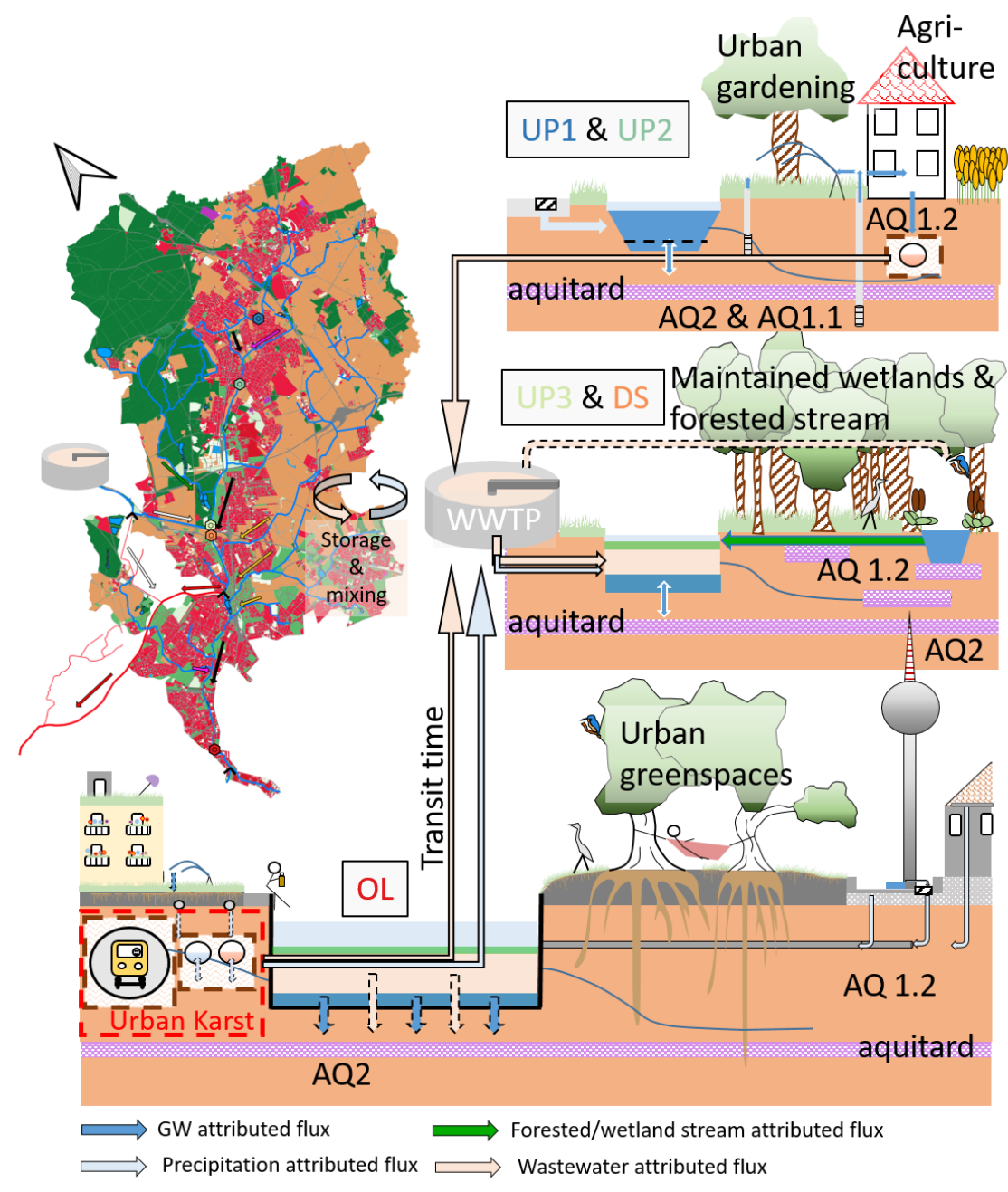

\section{Hosted file}

Table_1.pdf available at https://authorea.com/users/410242/articles/519702-isotope-hydrologyand-water-sources-in-a-heavily-urbanised-stream

\section{Hosted file}

Table_2.pdf available at https://authorea.com/users/410242/articles/519702-isotope-hydrologyand-water-sources-in-a-heavily-urbanised-stream

\section{Hosted file}

Table_3.pdf available at https://authorea.com/users/410242/articles/519702-isotope-hydrologyand-water-sources-in-a-heavily-urbanised-stream

\section{Hosted file}

Table_4.pdf available at https://authorea.com/users/410242/articles/519702-isotope-hydrologyand-water-sources-in-a-heavily-urbanised-stream 